\title{
Pengaruh PAD, SILPA, DAU, DAK dan DBH Terhadap Alokasi Belanja Modal: Studi Kasus Pada Pemerintah Kabupaten/Kota Provinsi Sumatera Utara, Bangka Belitung, Kepulauan Riau dan Bengkulu periode 2012-2018
}

\author{
Yohannes Cosmas Simbolon, Azhar Maksum, Erwin Abubakar \\ Program Studi Magister Ilmu Akuntansi, Universitas Sumatera Utara \\ Email corresponding author:yohannescosmas1234@gmail.com
}

\begin{abstract}
ABSTRAK
Penelitian ini bertujuan untuk mengetahui pengaruh Pendapatan Asli Daerah(PAD), Selisih Lebih Pembiayaan Anggaran (SiLPA) dan Dana Perimbangan (DAU, DAK dan DBH) terhadap pengalokasian anggaran belanja modal. Selain itu, penelitian ini juga akan menguji variabel pertumbuhan ekonomi yang dijadikan sebagai variabel pemoderasi. Jenis penelitian ini bersifat asosiatif. Populasi dalam penelian ini adalahPemerintahan Kabupaten/Kota di Provinsi Sumatera Utara, Bangka Belitung, Kepulauan Riau dan Bengkulu.Pengambilan Sampel dalam penelitian ini menggunakan teknik purposive sampling, maka jumlah sampel penelitian diketahui adalah sebanyak 46Kabupaten/Kota. Penelitian ini dilakukan untuk periode 2012-2018 yaitu 7 tahun maka jumlah observasi dalam penelitian ini adalah 322 obsrevasi. Jenis data yang digunakan adalah data sekunder dan teknik analisis data yang digunakan dalam penelitian ini adalah Analisis Regresi Data Panel dan Uji moderasi secara Interaksi dengen menggunakan software STATA. Hasil pengujian dalam penelitian ini pada alfa 5\% menunjukkan bahwaSiLPA, DAK dan DBH memiliki pengaruh yang positif dan signifikan terhadap pengalokasian anggaran belanja modal. Sedangkan PAD dan DAU tidak terbukti berpengaruh signifikan terhadap pengalokasian anggaran belanja modal pada Pemerintah Kabupaten/Kota di Provinsi Sumatera Utara, Bangka Belitung, Kepulauan Riau dan Bengkulu. Selain itu, variabel moderasi yang digunakan dalam penelitian ini yaitu pertumbuhan ekonomi terbukti mampu dijadikan sebagai variabel pemoderasi dalam pengaruh PAD dan DAU terhadap pengalokasian anggaran belanja modal. Namun pertumbuhan ekonomi tidak mampu dijadikan variabel moderasi pada pengaruh SiLPA, DAK dan DBH terhadap pengalokasian anggaran belanja modal.
\end{abstract}

Kata Kunci: PAD, SILPA, DAU, DAK, DBH, Belanja Modal

\section{PENDAHULUAN}

\section{Latar Belakang Masalah}

Pelaksanaan otonomi daerah dan desentralisasi fiskal, pada dasarnya mengandung tiga misi utama yaitu: (1) meningkatkan kualitas dan kuantitas pelayanan publik dan kesejahteraan masyarakat; (2) menciptakan efisiensi dan efektifitas pengelolaan sumber daya daerah; dan (3) memberdayakan dan menciptakan ruang bagi masyarakat (publik) untuk berpatisipasi dalam pembangunan (Mardiasmo, 2009). Anggaran daerah merupakan rencana keuangan yang dijadikan pedoman oleh Pemerintah Daerah dalam memberikan pelayanan kepada publik, dan di Indonesia, anggaran daerah disebut dengan APBD. 


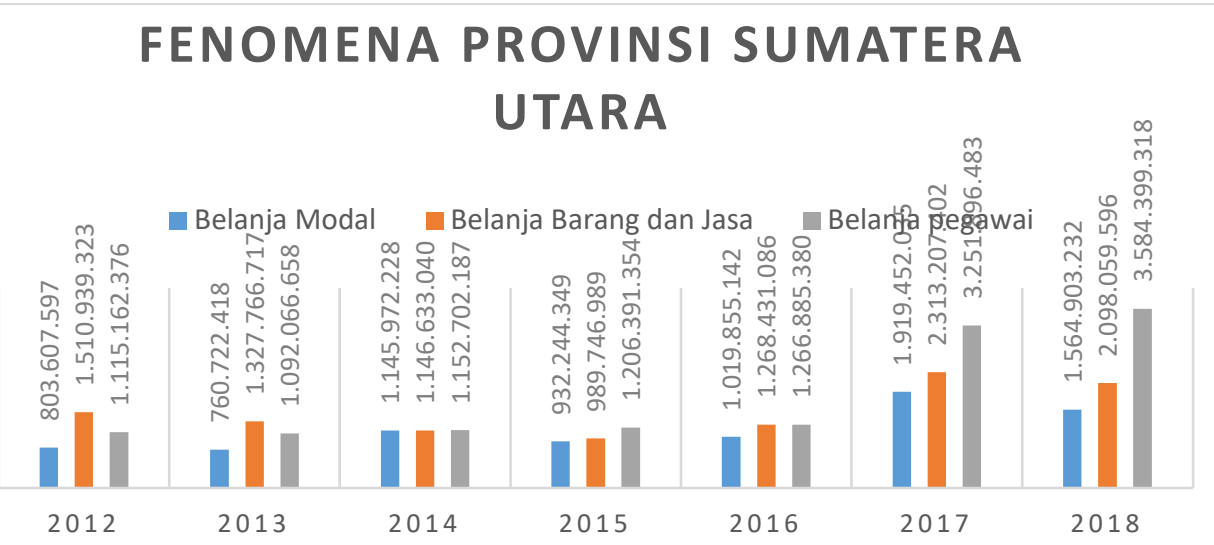

Gambar 1. Fenomena Belanja Daerah di Provinsi Sumatera Utara

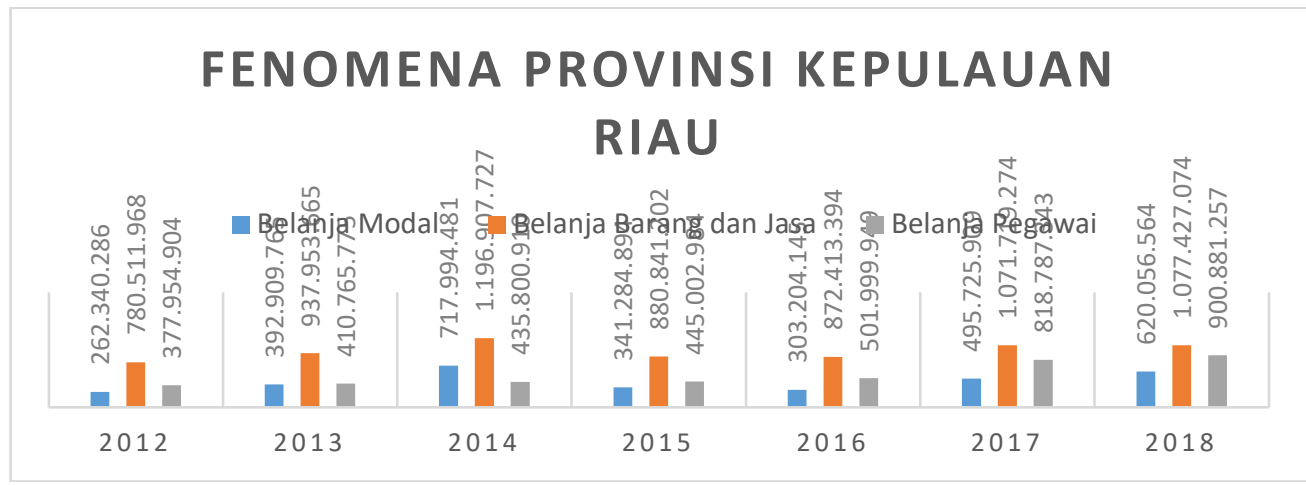

Gambar 2. Fenomena Belanja Modal Kepulauan Riau

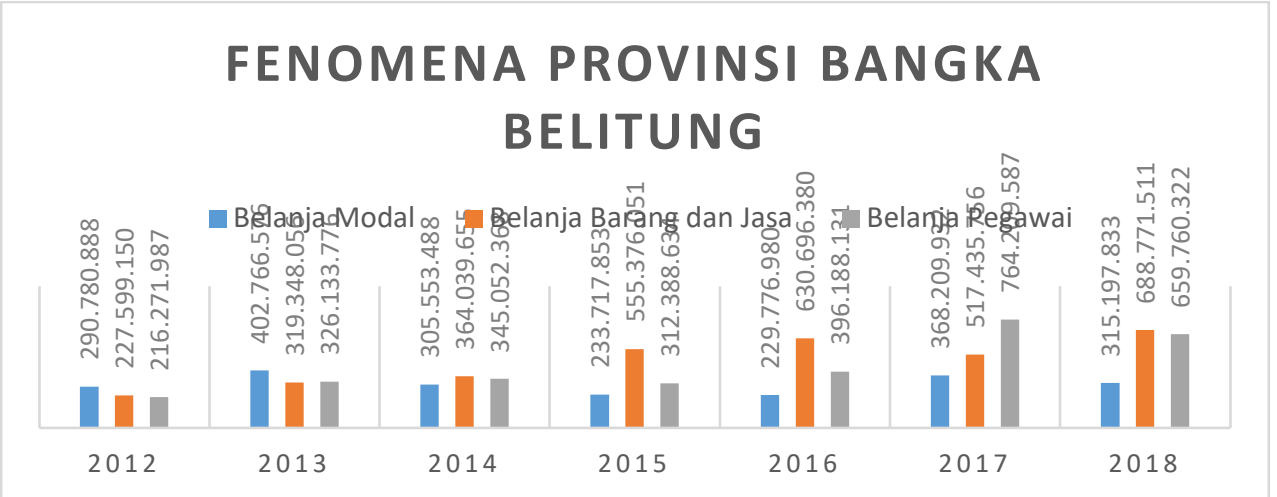

Gambar 3. Fenomena Belanja Modal Provinsi Bangka Belitung 


\section{FENOMENA PROVINSI BENGKULU}

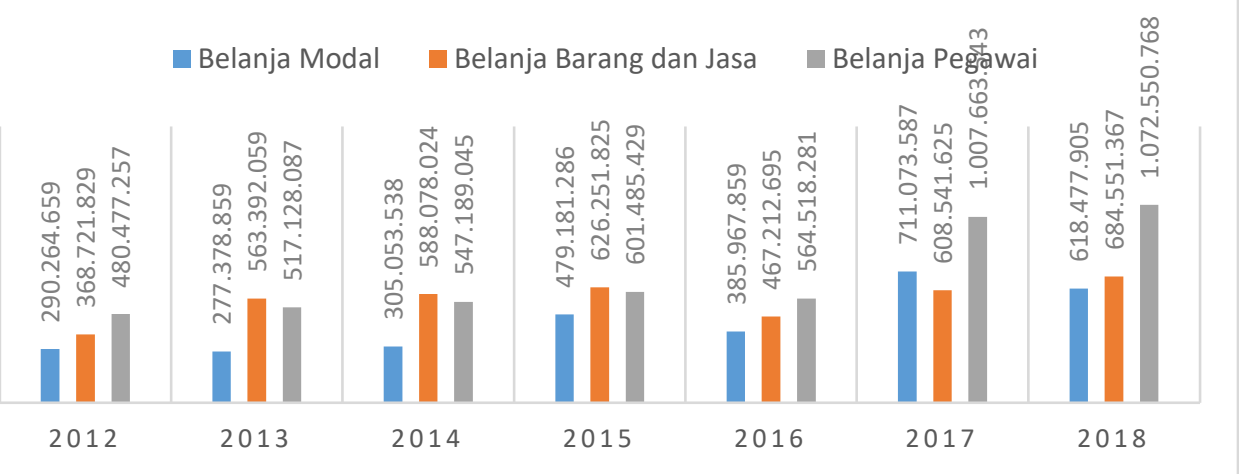

Gambar 4. Fennomena Belanja Modal Provinsi Bengkulu

Berdasakan Gambar di atas diketaui persentase alokasi belanja modal yang lebih kecil jika dibandingkan dengan belanja pegawai dan belanja barang dan jasa. Fenomena yang terjadi saat ini, yaitu lebih minimnya alokasi belanja modal yang dimiliki pemerintah jika dibandingkan belanja barang dan belanja pegawai yang secara tidak langsung menunjukkan ketidakberpihakan pemerintah kepada rakyat. Jika ingin meningkatkan pembangunan sekaligus meningkatkan pendapatan per kapita, pemerintah seharusnya memberi alokasi belanja modal lebih besar .

Pada pemerintah daerah, agar dapat memenuhi kebutuhan daerah dalam meningkatkan sarana dan prasarana, maka daerah memiliki beberapa sumber penerimaan daerah yang salah satunya berasal dari Pendapatan Asli Daerah (PAD). PAD merupakan semua penerimaan daerah yang berasal dari sumber ekonomi asli daerah. PAD bersumber dari hasil pajak daerah, hasil retribusi daerah, hasil pengelolaan kekayaan daerah yang dipisahkan, dan pendapatan lain asli daerah yang sah, yang bertujuan untuk memberikan keleluasaan kepada daerah dalam menggali pendanaan dalam pelaksanaan otonomi daerah sebagai perwujudan asas desentralisasi.

Dana Alokasi Umum (DAU), Dana Alokasi Khusus (DAK) dan Dana Bagi Hasil $(\mathrm{DBH})$. DAU pengalokasianya menekankan aspek pemerataan dan keadilan yang selaras dengan penyelenggaraan urusan pemerintahan. Selain itu, Pemerintah Pusat juga memberi kewenangan kepada Pemerintah Daerah dengan pengalihan dana, sarana dan Sumber Daya Manusia(SDM) . Pengalihan dana diwujudkan dalam bentuk dana perimbangan yaitu DAK. Sedangkan DBH adalah dana yang bersumber dari pendapatan Anggaran Pendapatan dan Belanja Negara(APBN) yang dialokasikan kepada Daerah berdasarkan angka persentase untuk mendanai kebutuhan Daerah dalam rangka pelaksanaan Desentralisasi.

SiLPA adalah Sumber pendanaan lainnya untuk alokasi belanja modal penyediaan berbagai fasilitas publik adalah penerimaan daerah yang bersumber dari Selisih Lebih Pembiayaan Anggaran (SiLPA) tahun anggaran sebelumnya. Menurut Peraturan Menteri Dalam Negeri (Permendagri) Nomor 13 tahun 2006, SILPA 
merupakan selisih dana yang diperoleh dari aktualisasi penerimaan serta pengeluaran anggaran daerah selama satu periode.

Pertumbuhan ekonomi yang baik (tinggi) harus didukung dengan insfrastruktur atau sarana dan prasarana yamg memadai guna memperlancar kegiatan ekonomi di daerah tersebut. Sehingga secara umum jika pertumbuhan ekonomi suatu daerah baik, maka pemerintah daerah setempat akan terus meningkatkan belanja modalnya dari tahun ke tahun guna melengkapi dan memperbaiki sarana dan prasarana. Hal ini lah yang membuat pertumbuhan ekonomi dapat memperkuat pengaruh antara PAD, SILPA dan SILPA dana perimbangan terhadap alokasi belanja modal pemerintah daerah.

\section{TINJAUAN PUSTAKA}

\section{Teori Keagenan (Agency Theory)}

Dalam teori keagenan Jensen dan Meckling (1976) menyatakan hubungan keagenan merupakan sebuah kontrak dimana satu atau lebih (principal) melimpahkan wewenang kepada orang lain (agen) untuk kepentingan mereka. Kaitan agency theory dalam penelitian ini dapat dilihat melalui hubungan antara Pemerintah Pusat Dengan Pemerintah Daerah dalam penyaluran dana perimbangan dan juga hubungan antara masyarakat yang diporsikan oleh Dewan Perwakilan Rakyat Daerah (principal) dengan Pemerintah Daerah (agen).

\section{Stewardship Theory}

Teori stewardship menjelaskan mengenai situasi manajemen tidaklah termotivasi oleh tujuan-tujuan individu melainkan lebih ditujukan pada sasaran hasil utama merekan untuk kepentingan organisasi (Donaldson, 1989 dan Davis, 1991). Teori ini mengambarkan tentang adanya hubungan yang kuat antara kepuasan dan kesuksesan organisasi. Sedangkan menurut Etty Murwaningsari (2009) Teori stewardship berdasarkan asumsi filosofis mengenai sifat manusia bahwa manusia dapat dipercaya, bertanggung jawab, dan manusia merupakan individu yang berintegritas.

\section{Birokrasi Teori}

Birokrasi pemerintah merupakan suatu organisasi yang memiliki struktur dan prosedur dalam mencapai tujuannya. Hal ini mengindikasi bahwa birokrasi merupakan organisasi yang didesain untuk menyelesaikan tugas administrasi secara sistematis berdasarkan urutan pekerjaan individu. Struktur birokrasi banyak diwarnai oleh karakteristik dan kapabilitas individu atau aparat selaku abdi negara atau pemerintah dan pelayan masyarakat yang secara hirarki sesuai dengan fungsi dan tanggung jawab dalam tata administrasi.. 


\section{Belanja Modal}

Belanja modal adalah belanja yang digunakan untuk pengeluaran yang dilakukan dalam rangka pembelian/pengadaan atau pembangunan aset tetap berwujud yang mempunyai nilai manfaat lebih dari 12 bulan untuk digunakan dalam kegiatan pemerintahan, seperti dalam bentuk tanah, peralatan dan mesin, gedung dan bangunan, jalan, irigasi dan jaringan, dan aset tetap lainnya Mardiasmo (2009).

\section{Pendapatan Asli Daerah}

PAD merupakan akumulasi dari Pos Penerimaan Pajak yang berisi Pajak Daerah dan Pos Retribusi Daerah,Pos Penerimaan Non Pajak yang berisi hasil perusahaan milik daerah, Pos Penerimaan Investasi serta PengelolaanSumber Daya Alam. PAD merupakan semua penerimaan daerah yang berasal dari sumber ekonomi asli daerah. Menurut Halim (2002), PAD merupakan semua penerimaan yang berasal dari sumber ekonomi asli daerah yang dipisahkan menjadi empat jenis pendapatan, yaitu: pajak daerah, retribusi daerah, hasil pengelolaan kekayaan milik daerah yang dipisahkan, lain-lain PAD yang sah.

\section{SiLPA}

Selisih Lebih Pembiayaan Anggaran (SiLPA) menurut Redha (2015) "merupakan penerimaan daerah yang bersumber dari selisih kas tahun anggaran Sebelumnya". Sesuai Permendagri Nomor 13 Tahun 2006. SiLPA sebenarnya merupakan indikator efisiensi, karena SiLPA hanya akan terbentuk bila terjadi surplus pada APBD dan sekaligus terjadi pembiayaan neto yang positif, dimana komponen penerimaan lebih besar dari komponen pengeluaran pembiayaan (Kusnandar dan Siswantoro, 2012).

\section{Dana Alokasi Umum}

DAU adalah salah satu dana perimbangan yang menjadi bagian dari sumber pendapatan daerah. DAU dialokasikan berdasarkan presentase tertentu dari pendapatan dalam negeri neto yang ditetapkan dalam APBN yang dialokasikan dengan tujuan pemerataan keuangan antar daerah untuk membiayai kebutuhan pengeluaran daerah masing-masing dalam rangka pelaksanaan desentralisasi.

\section{Dana Alokasi Khusus}

Dana alokasi khusus (DAK) merupakan salah satu mekanisme transfer keuangan Pemerintah Pusat ke daerah yang bertujuan antara lain untuk meningkatkan penyediaan sarana dan prasarana fisik daerah sesuai prioritas nasional serta mengurangi kesenjangan laju pertumbuhan antar daerah dan pelayanan antar bidang. DAK memainkan peran penting dalam dinamika pembangunan sarana dan prasarana pelayanan dasar di daerah karena sesuai dengan prinsip desentralisasi tanggung jawab dan akuntabilitas bagi penyediaan pelayanan dasar masyarakat telah dialihkan kepada pemerintah daerah (Siahaan, 2016). 


\section{Dana Bagi Hasil}

Menurut Peraturan Pemerintah Nomor 55 Tahun 2005 Dana Bagi Hasil adalah dana yang bersumber dari pendapatan APBD yang dialokasikan kepada Daerah berdasarkan angka persentase yang kemudian dialokasikan kepada daerah dengan memperhatikan potensi daerah penghasil untuk melihat angka persentase tertentu untuk mendanai kebutuhan daerah dalam rangka pelaksanaan penyerahan desentralisasi dari pusat kepada daerah (Listiorini, 2012).

\section{Kerangka Berfkir}

Adapun kerangka berfikir dalam penelitian ini dapat digambarkan sebagai berikut:

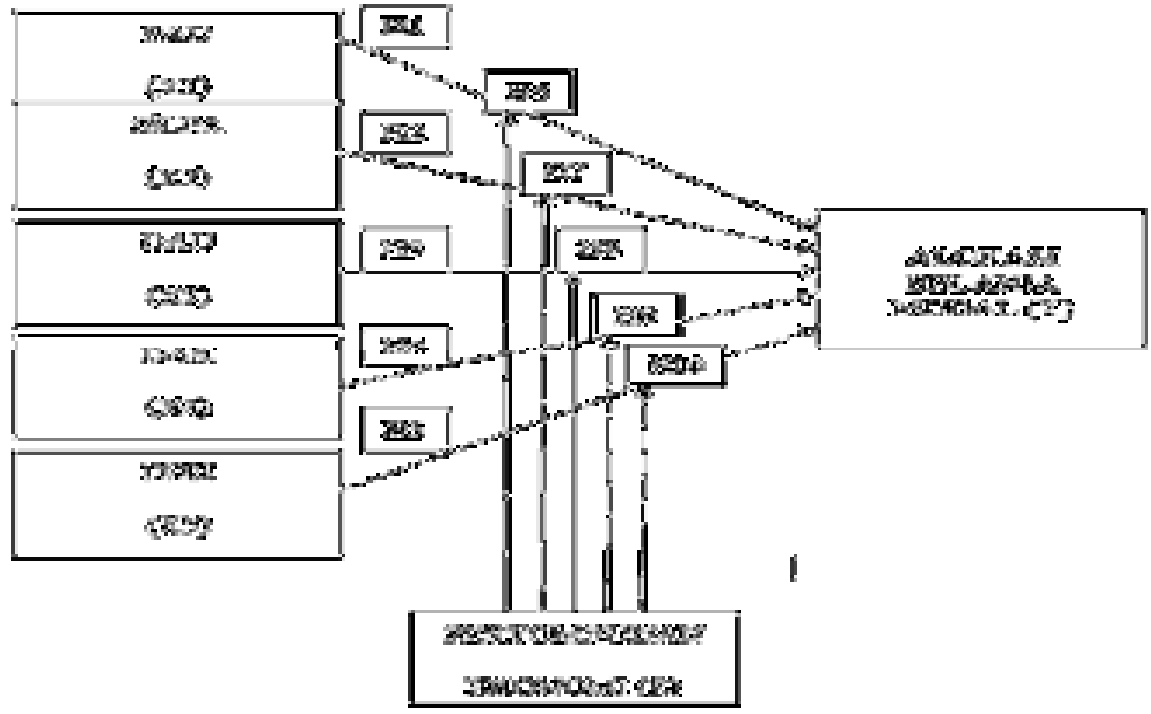

Gambar 5. Kerangka Konseptual

\section{Hipotesis Penelitian}

Hipotesis 1: PAD berpengaruh positif terhadap pengalokasian anggaran belanja modal pada Pemerintah Kabupaten/Kota di Provinsi Sumatera Utara, Kepulauan Riau, Bangka Belitung dan Bengkulu.

Hipotesis 2 : SiLPA berpengaruh positif terhadap pengalokasian anggaran belanja modal pada Pemerintah Kabupaten/Kota di Provinsi Sumatera Utara, Kepulauan Riau, Bangka Belitung dan Bengkulu.

Hipotesis 3: DAU berpengaruh positif terhadap pengalokasian anggaran belanja modal pada Pemerintah Kabupaten/Kota di Provinsi Sumatera Utara, Kepulauan Riau, Bangka Belitung dan Bengkulu.

Hipotesis 4: DAK berpengaruh positif terhadap pengalokasian anggaran belanja modal pada Pemerintah Kabupaten/Kota di Provinsi Sumatera Utara, Kepulauan Riau, Bangka Belitung dan Bengkulu. 
Hipotesis 5: DBH berpengaruh positif terhadap pengalokasian anggaran belanja modal pada Pemerintah Kabupaten/Kota di Provinsi Sumatera Utara, Kepulauan Riau, Bangka Belitung dan Bengkulu.

Hipotesis 6: Pertumbuhan Ekonomi dapat memoderasi pengaruh antara PAD terhadap pengalokasian anggaran belanja modal pada Pemerintah Kabupaten/Kota di Provinsi Sumatera Utara, Kepulauan Riau, Bangka Belitung dan Bengkulu.

Hipotesis 7 : Pertumbuhan Ekonomi dapat memoderasi pengaruh antara SiLPA terhadap pengalokasian anggaran belanja modal pada Pemerintah Kabupaten/Kota di Provinsi Sumatera Utara, Kepulauan Riau, Bangka Belitung dan Bengkulu.

Hipotesis 8: Pertumbuhan Ekonomi dapat memoderasi pengaruh antara DAU terhadap pengalokasian anggaran belanja modal pada Pemerintah Kabupaten/Kota di Provinsi Sumatera Utara, Kepulauan Riau, Bangka Belitung dan Bengkulu.

Hipotesis 9: Pertumbuhan Ekonomi dapat memoderasi pengaruh antara DAK terhadap pengalokasian anggaran belanja modal pada Pemerintah Kabupaten/Kota di Provinsi Sumatera Utara, Kepulauan Riau, Bangka Belitung dan Bengkulu.

Hipotesis 10 :Pertumbuhan Ekonomi dapat memoderasi pengaruh antara DBH terhadap pengalokasian anggaran belanja modal pada Pemerintah Kabupaten/Kota di Provinsi Sumatera Utara, Kepulauan Riau, Bangka Belitung dan Bengkulu.

\section{METODE PENELITIAN}

\section{Metode Penelitian}

Desain penelitian ini dilakukan berdasarkan penelitian asosiatif. Penelitian asosiatif adalah penelitian yang bertujuan untuk mengetahui hubungan antar dua variabel atau lebih. Jenis penelitianini digolongkan pada penelitian assosiatif kausal yang bertujuan untuk menjelaskan fenomena dalam bentuk hubungan antara variabel. Tujuan utama dari jenis penelitian ini adalah mengidentifikasi hubungan sebab akibat antara berbagai variabel (Erlina, 2011).

Populasi dalam penelitian ini adalah pemerintah daerah kabupaten/kota di Provinsi Sumatera Utara, Kepulauan Riau, Bangka Belitung dan Bengkulu,yang berjumlah 57 Kabupaten/Kota. Data sampel diambil dengan menggunakan purposive sampling, yaitu teknik penentuan sampel dengan pertimbangan tertentu.Metode pengumpulan data yang dilakukan dalam penelitian ini adalah dokumentasi, dimana data yang diambil melalui media perantara yaitu internet.

Dalam menganalisis pengaruh dari PAD, SiLPA,DAU, DAK dan DBH terhadap pengalokasian anggaran belanja modal dengan pertumbuhan ekonomi yang 
dijadikan sebagai variabel moderating digunakan Analisis Regresi Linear Berganda dengan variabel dependen yaitu pengalokasian anggaran belanja modal dan variabel independen yaitu PAD, SiLPA,DAU, DAK, dan DBH. Serta variabel moderating yaitu pertumbuhan ekonomiyang akan diuji dengan menggunakan Uji Interaksi. Untuk menguji data dan juga hipotesis penelitian maka dilakukan beberpa pengujian dengan bantuan softwareSTATA.

\section{HASIL PENELITIAN DAN PEMBAHASAN}

\section{Nilai statistik dari Koefisien Determinasi,Uji F, dan Uji $t$}

\begin{tabular}{|c|c|c|c|c|c|c|c|}
\hline Source & \multicolumn{4}{|c|}{ MS } & & \multicolumn{2}{|c|}{ Number of obs $=\quad 322$} \\
\hline & & & & & & F $(5$, & 10.32 \\
\hline Model & 52.7893071 & 5 & 10 & 78614 & & Prob > F & 0.0000 \\
\hline Residual & 323.132931 & 316 & 1.02 & 57257 & & R-squared & 0.1404 \\
\hline Total & 375.922238 & 321 & $1.1^{\prime}$ & 9731 & & Root MSE & 1.0112 \\
\hline Y & Coef. & Std. & Err. & t & $P>|t|$ & [95\% Conf. & Interval] \\
\hline $\mathrm{x} 1$ & .0034827 & .0685 & 989 & 0.05 & 0.960 & -.1314855 & .1384509 \\
\hline $\mathrm{x} 2$ & .1286439 & .0641 & 325 & 2.01 & 0.046 & .0024632 & .2548245 \\
\hline x3 & .1401527 & .0731 & 727 & 1.92 & 0.056 & -.0038145 & .2841199 \\
\hline$\times 4$ & .1949891 & .0621 & 658 & 3.14 & 0.002 & .0726779 & .3173003 \\
\hline$\times 5$ & .1369807 & .0643 & 716 & 2.13 & 0.034 & .0103296 & .2636318 \\
\hline _cons & -7.043453 & .9920 & 202 & -7.10 & 0.000 & -8.995252 & -5.091653 \\
\hline
\end{tabular}

Diketahui bahwa nilai koefisien determinasi ( $R$-squared) sebesar $R^{2}=0,1404$. Nilai tersebut dapat diartikan PAD, SILPA, DAU, DAK, DBH secara simultan atau bersama-sama mempengaruhi alokasi belanja modal sebesar 14,04\%, selisihnya sebesar $85,96 \%$ dipengaruhi oleh faktor-faktor lain yang tidak diteliti dalam penelitian ini.

Uji Simultan (Uji F)bertujuan untuk menguji pengaruh variabel bebas secara bersamasama atau simultan terhadap variabel tidak bebas. Berdasarkan Tabel 5.7, diketahui bahwa nilai Probabilitas $<\alpha$, yakni 0,000<0,05, maka dapat disimpulkan bahwa seluruh variabel bebas, yakni PAD, SILPA, DAU, DAK, DBH secara simultan berpengaruh signifikan terhadap variabel alokasi belanja modal.

Berdasarkan Tabel 5.7, diperoleh persamaan regresi sebagai berikut :

$\mathrm{Y}=-7,04+0,003 \mathrm{X} 1+0,128 \mathrm{X} 2+0,140 \mathrm{X} 3+0,194 \mathrm{X} 4+0,136 \mathrm{X} 5+\mathrm{e}$

Berdasarkan Tabel 5.7, diketahui bahwa :

$\Rightarrow$ Diketahui PAD berpengaruh positif terhadap alokasi belanja modal, dengan nilai koefisien regresi 0,0034, namun tidak signifikan, dengan nilai probabilitasabilitas $0,960>0,05$. Sehingga PAD berpengaruh positif terhadap alokasi belanja modal, namun tidak signifikan. H1ditolak 
$\Rightarrow$ Diketahui SILPA berpengaruh positif terhadap alokasi belanja modal, dengan nilai koefisien regresi 0,1286, dan signifikan, dengan nilai probabilitasabilitas $0,046<0,05$. Sehingga SILPA berpengaruh positif dan signifikan terhadap alokasi belanja modal. $\mathrm{H} 2$ diterima

$\Rightarrow$ Diketahui DAU berpengaruh positif terhadap alokasi belanja modal, dengan nilai koefisien regresi 0,1401, namun tidak signifikan, dengan nilai probabilitasabilitas 0,056 $>0,05$. Sehingga DAU berpengaruh positif terhadap alokasi belanja modal, namun tidak signifikan. H3 ditolak

$\Rightarrow$ Diketahui DAK berpengaruh positif terhadap alokasi belanja modal, dengan nilai koefisien regresi 0,1949 , dan signifikan, dengan nilai probabilitasabilitas $0,002<0,05$. Sehingga DAK berpengaruh positif dan signifikan terhadap alokasi belanja modal. H4 diterima

$\Rightarrow$ Diketahui DBH berpengaruh positif terhadap alokasi belanja modal, dengan nilai koefisien regresi 0,1369 , dan signifikan, dengan nilai probabilitasabilitas $0,034<0,05$. Sehingga DBH berpengaruh positif dan signifikan terhadap alokasi belanja modal. H5 diterima

Pengujian pertumbuhan ekonomi Dalam Memoderasi Pengaruh PAD, SiLPA, DAU, DAK, DBH Terhadap Alokasi Belanja Modal

\begin{tabular}{|c|c|c|c|c|c|c|c|}
\hline source & SS & $d \pm$ & \multicolumn{2}{|c|}{ MS } & & $\begin{array}{l}\text { Number of obs } \\
\text { F( } 11, \text { (10) }\end{array}$ & \multirow{4}{*}{$\begin{array}{r}322 \\
8.40 \\
0.0000 \\
0.2296 \\
0.2022\end{array}$} \\
\hline Mode 1 & 862997877 & 17 & \multirow{2}{*}{\multicolumn{2}{|c|}{$\begin{array}{l}7.84543519 \\
.934265971\end{array}$}} & & Prob $>F$ & \\
\hline Residual & 289.622451 & 310 & & & & $\begin{array}{l}\text { Prob }>F \\
\text { R-squared }\end{array}$ & \\
\hline & & & & & & \multirow{2}{*}{$\begin{array}{l}\text { Adj R-squared } \\
\text { Root MSE }\end{array}$} & \\
\hline Total & 375.922238 & 321 & 1.1 & 9731 & & & .96657 \\
\hline Y & Coef. & sta. & Err. & t & $P>|t|$ & [95\% Conf. & Interval] \\
\hline$\times 1$ & .4529662 & .1182 & 579 & 3.83 & O. O O O & .2202765 & .6856558 \\
\hline$\times 2$ & .5318867 & $.533 c$ & 738 & 1.00 & 0.319 & -.5170138 & 1.580787 \\
\hline$\times 3$ & .1420152 & .070 & 447 & 2.03 & 0.043 & .0041921 & .2798384 \\
\hline$\times 4$ & .1235289 & .0624 & 192 & 1.98 & 0.049 & .0007099 & .2463479 \\
\hline$\times 5$ & .2065309 & .0652 & 642 & 3.16 & 0.002 & .078114 & .3349477 \\
\hline z & .6374455 & .708 & 752 & 0.90 & 0.369 & -.7571275 & 2.032018 \\
\hline$x 1 z$ & -.0333692 & .0108 & 551 & -3.07 & 0.002 & -.0547282 & -.0120101 \\
\hline$x 2 z$ & -.0502251 & .0602 & 155 & -0.83 & 0.405 & -.1687078 & .0682576 \\
\hline$\times 3 z$ & .0000203 & 8.18 & -06 & 2.48 & 0.014 & $4.18 e-06$ & .0000364 \\
\hline$\times 4 z$ & $-1.86 e-09$ & 4.86 & -09 & -0.38 & 0.702 & $-1 \cdot 14 e-08$ & $7.70 e-09$ \\
\hline$\times 5 z$ & $4.95 e-10$ & 1.536 & -09 & 0.32 & 0.747 & $-2.52 e-09$ & $3.52 e-09$ \\
\hline _cons & -13.75413 & 6.08 & 041 & -2.26 & 0.025 & -25.72931 & -1.778958 \\
\hline
\end{tabular}

Berdasarkan hasil pengujian moderasi pada Tabel 5.8, diperoleh hasil bahwa nilai probabilitasdari $\mathrm{X} 1 \mathrm{Z}$ adalah $0,002<$ tingkat signifikansi 0,05, maka disimpulkan pertumbuhan ekonomi signifikan dalam memoderasi pengaruh PAD terhadap alokasi belanja modal.X2Z memiliki nilai probabilitas sebesar 0,405> tingkat signifikansi 0,05, yang berarti bahwa pertumbuhan ekonomi tidak signifikan dalam memoderasi pengaruh SiLPA terhadap alokasi belanja modal.Diketahui nilai Probabilitasdari X3Z adalah 0,014 < tingkat signifikansi 0,05, maka dapat disimpulkan pertumbuhan ekonomi signifikan dalam memoderasi pengaruh DAU terhadap alokasi belanja modal.X4Z memiliki nilai probabilitas sebesar 0,720 > tingkat 
signifikansi 0,05, yang berarti bahwa pertumbuhan ekonomi tidak signifikan dalam memoderasi pengaruh DAK terhadap alokasi belanja modal.Diketahui nilai Probabilitasdari X5Z adalah 0,747 > tingkat signifikansi 0,05, maka disimpulkan pertumbuhan ekonomi tidak signifikan dalam memoderasi pengaruh DBH terhadap alokasi belanja modal.

Berdasarkan hasil tersebut maka dapat disimpulkan bahwa pertumbuhan ekonomi hanya mampu memoderasi dua variabel yaitu mampu memoderasi dan memperkuat pengaruh PAD dan DAU terhadap alokasi belanja modal. Namun pertumbuhan ekonomi tidak mampu memoderasi pengaruh SiLPA, DAK dan DBH terhadap alokasi belanja modal.

Berdasarkan hasil pengujian dalam penelitian ini dapat diketahui bahwa PAD tidak berpengaruh signifikan terhadap alokasi belanja modal, hal ini dapat dikarenakan adanilai PAD yang rentangnya sangat jauh antar provinsi. Daerah dengan PAD rendah kemungkinan dikarenakan kurangnya penggalian sumbersumber penerimaan baru (ekstensifikasi), seharusnya setiap daerah meningkatkan PAD melalui upaya ekstensifikasi yaitu dengan meningkatkan kegiatan ekonomi masyarakat, upaya ini harus diarahkan dengan mempertahankan dan menggali potensi daerah agar dapat dimanfaatkan secara berkelanjutan. Hasil dalam penelitian ini sejalan dengan penelitian terdahulu yang dilakukanoleh Yovita (2011) yang dalam penelitiannya juga menyatakan,provinsi dengan PAD yang besar cenderung tidak memiliki belanja modal yang besar

Berdasarkan hasil dalam penelitian ini diperoleh bahwa SiLPA memiliki pengaruhyang signifikan terhadap alokasi belanja modal.SiLPA akan meningkat apabila belanja modal naik, sebaliknya bila SiLPA relatif menurun, maka alokasibelanja modal cenderung menurun. Hal ini menunjukan salah satu indikasi bahwa penggunaan SiLPA telah sesuai dengan aturan penggunaan yang diatur dalam Permendagri Nomor 13 Tahun 2006 Pasal 137, antara lain untuk mendanai kegiatan lanjutan dan mendanai kewajiban lain yang sampai dengan akhir tahun anggaran belum diselesaikan. Beberapa proyek pembangunan infrastruktur yang membutuhkan waktu yang lama terkadang belum selesai dan melewati tahun anggaran sehingga alokasi belanja modal yang belum terealisasi akan meningkatkan terjadinya peningkatan alokasi belanja modal dan menjadi SiLPA di tahun berikutnya. Sehingga apabila SiLPA tinggi menandakan tinggi pula alokasi belanja modal yang terjadi. Hasil penelitian ini sejalan dengan hasil penelitian Bungkes et al. (2016);

Berdasarkan hasil dalam penelitian ini diperoleh bahwa DAU memiliki pengaruh tidak signifikan terhadap belanja modal dengan arah positif. Hasil ini menjelaskan bahwa pemerintah daerah kabupaten/kota di Provinsi Sumatera Utara, Kepulauan Riau, Bangka Belitung dan Bengkulu yang mendapatkan DAU yang besar akan cenderung memiliki belanja modal yang rendah. Hal ini terjadi karena DAU 
lebih digunakan untuk membiayai belanja operasi seperti belanja pegawai dan belanja barang. Hasil penelitian ini sejalan dengan hasil penelitian Verawaty, dkk. (2015);

Berdasarkan hasil penelitian diperoleh bahwa DAK memiliki pengaruh positif dan signifikan terhadap belanja modal, artinya ketika Dana Alokasi Khusus (DAK) meningkat sebesar 1 satuan, maka Alokasi Belanja Modal akan meningkat.Hasil ini menjelaskan bahwa pemerintah daerah kabupaten/kota di Provinsi Sumatera Utara, Kepulauan Riau, Bangka Belitung dan Bengkulu, yang mendapatkan DAK yang besar akan cenderung memiliki belanja modal yang besar pula. Hal ini memberikan adanya indikasi yang kuat bahwa perilaku belanja modal akan sangat dipengaruhi dari sumber penerimaan DAK. Hasil penelitian ini sejalan dengam penelitian sebelumnya yang dilakukan oleh Asrul Wisnu Setiawan (2015) menyatakan bahwa DAK berpengaruh signifikan terhadap belanja modal.

Berdasarkan hasil penelitian diperoleh bahwa DBH memiliki pengaruh yang signifikan terhadap belanja modal. Hasil ini menjelaskan bahwa provinsi yang mendapatkan $\mathrm{DBH}$ yang besar akan cenderung memiliki belanja modal yang besar pula. Hasil ini memberikan adanya indikasi yang kuat bahwa perilaku belanja modal akan sangat dipengaruhi dari sumber penerimaan $\mathrm{DBH}$. DBH merupakan sumber pendapatan daerah yang cukup potensial dan merupakan salah satu modal dasar pemerintah daerah dalam mendapatkan dana pembangunan dan memenuhi belanja daerah yang bukan berasal dari PAD selain DAU dan DAK. Pola bagi hasil penerimaan tersebut dilakukan dengan presentase tertentu yang didasarkan atas daerah penghasil. Hal ini sejalan dengan penelitian yang dilakukan oleh Darmayasa (2014) yang memberikan hasil bahwa DBH berpengaruh signifikan terhadap belanja modal.

Dalam penelitian ini menyatakan bahwa pertumbuhan ekonomi mampu memoderasi hubungan PAD terhadap pengalokasian anggaran belanja modal pada Pemerintah Daerah Kabupaten/Kota di Provinsi Sumatera Utara, Kepulauan Riau, Bangka Belitung dan Bengkulu. Hasil pengujian dalam penelitian ini menunjukkan bahwa interaksi antara pertumbuhan ekonomi dan PAD memiliki pengaruh yang signifikan terhadap pengalokasian anggaran belanja modal karena nilaisignifikansinya lebih kecil dari tingkat signifikansi 5\% (0,05). Pertumbuhan ekonomi pada daerah yang meningkat akan berdampak pada peningkatan pendapatan per kapita penduduk, sehingga tingkat konsumsi dan produktivitas penduduk akan semakin meningkat pula. Selain itu, semakin tinggi pendapatan yang diperoleh masyarakat, maka semakin tinggi pula kemampuan masyarakat untuk membayar pungutan yang telah ditetapkan oleh pemerintah daerah. Hal ini akan meningkatkan sumber penerimaan daerah dan tentu saja akan membuat penerimaan PAD semakin tinggi.

Dalam penelitian ini menyatakan bahwa pertumbuhan ekonomi tidak mampu dalam memoderasi hubunganSiLPA terhadap pengalokasian anggaran belanja modal pada Pemerintah Daerah Kabupaten/Kota di Provinsi Sumatera Utara, 
Kepulauan Riau, Bangka Belitung dan Bengkulu. Hal ini disebabkan adanya masalah keagenan yang di timbul dikalangan eksekutif (pempus) cenderung memaksimalkan utility (selfinterest) dalam pembuatan atau penyusunan APBD, karena memiliki asimetri informasi. Akibatnya eksekutif cenderung melakukan "budgetaryslack". Adanya kesenjangan dapat mengakibat kan pertumbuhan ekonomi terganggu tidak mampu memoderasi pengaruh SiLPA terhadap Belanja Modal. Hasil Penelitian ini sejalan dengan Hardiningsih (2017) bahwa Pertumbuhan Ekonomi tidak terbukti memodeasi pengaruh Selisih Lebih Pembiayaan Anggaran terhadap Belanja Modal.

Dalam penelitian ini menyatakan bahwa pertumbuhan ekonomi mampu memoderasi hubunganDAU terhadap pengalokasian anggaran belanja modal pada Pemerintah Daerah Kabupaten/Kota di Provinsi Sumatera Utara, Kepulauan Riau, Bangka Belitung dan Bengkulu.Pemerintah daerah masih banyak yang membutuhkan dana bantuan dari pemerintah pusat untuk meningkatkan sarana dan prasarana publik dalam meningkatkan pembangunan daerah. Hasil penelitian sejalan dengan penelitianSugiarthi dan Supadmi (2014) menyatakan bahwa Pertumbuhan Ekonomi berpengaruh dan mampu memoderasi pengaruh DAU pada Alokasi Belanja Modal. Jadi dapat disimpulkan pertumbuhan ekonomi dapat memoderasi atau berpengaruh hubungan antara Dana Alokasi Umum pada Alokasi Belanja Modal.

Dalam penelitian ini menyatakan bahwa pertumbuhan ekonomi tidak mampu dalam memoderasi hubunganDAK terhadap pengalokasian anggaran belanja modal pada Pemerintah Daerah Kabupaten/Kota di Provinsi Sumatera Utara, Kepulauan Riau, Bangka Belitung dan Bengkulu. Hasil penelitian ini menunjukan Tinggi rendahnya pertumbuhan ekonomi suatu daerah, tidak menjadi pertimbangan pemerintah daerah ketika memanfaatkan dana alokasi khusus dalam belanja modal. sejalan dengan penelitian Sari dan Wirama (2018) yang menyatakan bahwa pertumbuhan ekonomi tidak memoderasi hubungan Antara Dana Alokasi Khusus dengan belanja modal. Hasil penelitian ini sejalan dengan hasil penelitian yang dilakukan oleh Prabawati dan Cahyaning (2018) yang menyatakan bahwa pertumbuhan ekonomi tidak dapat memoderasi pengaruh Dana Alokasi Umum terhadap alokasi belanja modal.

Dalam kegiatan perekonomian yang sebenarnya, pertumbuhan ekonomi menunjuk kan peningkatan secara fisik terhadap produksi barang dan jasa yang berlaku di suatu daerah. Peningkatan ini dapat dilihat dari bertambahnya produksi barang industri, berkembangnya infra struktur, bertambahnya jumlah sekolah, bertambahnya produksi barang modal dan bertambahnya sektor jasa di daerah tersebut. Jadi, jika suatu daerah mengalami peningkatan pertumbuhan ekonomi, maka DBH yang didapatkan daerah juga semakin meningkat, hal inilah yang memungkinkan daerah untuk memperoleh alokasi belanja modal yang lebih besar di waktu yang akan datang. 


\section{KESIMPULAN DAN SARAN}

\section{Kesimpulan}

PAD dan DAUmemiliki pengaruhtidaksignifikan terhadap pengalokasian anggaran belanja modal pada Pemerintah Kabupaten/Kota di Provinsi Sumatera Utara, Kepulauan Riau, Bangka Belitung dan Bengkulu. Sedangkan SiLPA, DAK dan DBHmemiliki pengaruh yang positif dan signifikan terhadap pengalokasian anggaran belanja modal pada Pemerintah Kabupaten/Kota di Provinsi Sumatera Utara, Kepulauan Riau, Bangka Belitung dan Bengkulu.Pertumbuhan ekonomi tidak dapat memoderasi pengaruhSiLPA, DAK dan DBH terhadap pengalokasian anggaran belanja modal pada Pemerintah Kabupaten/Kota di Provinsi Sumatera Utara, Kepulauan Riau, Bangka Belitung dan Bengkulu. Sedangkan Pertumbuhan ekonomi dapat memoderasi pengaruh PAD dan DAU terhadap pengalokasian anggaran belanja modal pada Pemerintah Kabupaten/Kota di Provinsi Sumatera Utara, Kepulauan Riau, Bangka Belitung dan Bengkulu. Sehingga H8diterima.

\section{Saran}

1. Penelitian selanjutnya diharapkan agar kembali menguji pengaruh variabelvariabel lain yang dapat mempengaruhi belanja modal pada Pemerintah Daerah di Provinsi Sumatera Utara, Kepulauan Riau, Bangka Belitung dan Bengkulu. Beberapa variabel yang dapat diteliti, ukuran pemerintah daerahdan sebagainya.

2. Dalam hasil penelitian ini dapat diketahui bahwa pertumbuhan ekonomi tidak dapat dijadikan sebagai variabel moderating dalam pengaruh DAU dan DBHterhadap pengalokasian anggaran belanja modal Pemerintah Daerah di Provinsi Sumatera Utara, Kepulauan Riau, Bangka Belitung dan Bengkulu. Sehingga dalam penelitian selanjutnya diharapkan kembali menguji kembali variabel pemoderasi pertumbuhan ekonomi pada Pemerintah Daerah lainnya Indonesia untuk mengetahui apakah pertumbuhan ekonomi dapat dijadikan sebagai variabel moderating terhadap belanja modal secara keseuruhan atau tidak.

\section{DAFTAR PUSTAKA}

Asrul Wisma Setiawan (2015) Pengaruh Pertumbuhan Ekonomi, Pendapatan Asli Daerah, Dana Alokasi Umum, Dana Alokasi Khusus dan Dana Bagi Hasil Terhadap Pengalokasin Anggaran Belanja Modal di Kabupaten/Kota di Yogyakarta Periode Tahun 2007-2013.

Alfasadun, Hardiningsih, Pancawati Dan Wakhidati, Indri Nur. 2017. Karakteristik Daerah Terhadap Belanja Modal Dengan Pemoderasi Pertumbuhan Ekonomi. Dinamika Akuntansi, Keuangan Dan Perbankan, Mei 2017, Hal: 53- 66Yustika, 
A.E. (2012). Economic Reform and Weak of the Institutional Change in Indonesia. International Journal of Humanities and Sosial Science. 2 (2).

Bungkes, P., Nadirsyah, \&Abdullah, S. (2016). Pengaruh Dana Perimbangan, Pendapatan Sendiri dan Penerimaan Pembiayaan Terhadap Belanja Modal (Studi pada Pemerintahan Kabupaten/Kota di Aceh). Jurnal Magister Akuntansi. Universitas Syiah Kuala. 5 (3). 50-59.

Cahyaning, S. (2018). Pengaruh Pendapatan Asli Daerah, Dana Alokasi Umum dan Dana Bagi Hasil Terhadap Alokasi Belanja Modal Dengan Pertumbuhan Ekonomi Sebagai Variabel Moderating Pada Pemerintah Daerah Kabupaten/Kota Provinsi Jawa Timur Tahun 2013-2015. Jurnal Ilmu Ekonomi Terapan.3 (1). 1-38.

Donaldson, L., \& Davis, J.H. 1989. CEO governance and shareholder returns: Agency theory or stewardship theory. Paper presented at the annual meeting of the Academy of Management, Washington, DC.

Halim, Abdul. 2002. Manajemen Keuangan Daerah. Yogyakarta: UPP STIM YKPN

James H. Davis, F. David Scoorman dan Lex Donalson. 1997. "Toward a Stewardship Theory of Management." Academy of Management Review Vol. 22, No. 1, page 2247, 1997.

Jensen, M. C., \& Meckling, W. H. (1976). Theory of the firm: Managerial behavior, agency costs and ownership structure. Journal of financial economics, 3(4), 305-360.

Listiorini. 2012. Fenomena Flypaper Effect pada Dana Perimbangan dan Pendapatan Asli Daerah Terhadap Belanja Daerah pada kabupaten/kota di Sumatera Utara. Jurnal Keuangan dan Bisnis. Vol.4 No. 2, Juli: 111-126.

Murwaningsari, E. (2010). Hubungan Corporate Governance, Corporate Social Responsibilities dan Corporate Financial Performance Dalam Satu Continuum. Jurnal Akuntansi dan keuangan, 11(1), pp-30.

Mardiasmo. (2009). Akuntansi Sektor Publik. Yogyakarta: ANDI.

Peraturan Menteri Dalam Negeri Nomor 13 tahun 2006

Putro, P. Utama. (2013) Pengaruh PDRB Ddan Ukuran Terhadap Pengendalian Intern Pemerintah Daerah Dengan PAD Sebagai Variabel Intervening. E jurnal Undip. 1 (1). 1-15

Prabawati, P. \&Wany, E. (2017). Pengaruh Pendapatan Asli Daerah, Dana Alokasi Umum dan Dana Bagi Hasil Terhadap Alokasi Belanja Modal Dengan Pertumbuhan Ekonomi Sebagai Variabel Moderating Pada Pemerintah Daerah Kabupaten/Kota Provinsi Jawa Timur Tahun 2013-2015. Jurnal Equilibrium, Edisi Khusus. 1 (1). 1-17.

Pemendragi Nomor 13 Tahun 2006,Peraturan Pemrintah Nomor 55tahun 2005, Pemendagri Nomor 13 Tahun 2006 Pasal 137

Syairozi, M., Rosyad, S., \& Pambudy, A. P. (2019). Pemberdayaan Masyarakat Sebagai Pengguna Kosmetik Alami Beribu Khasiat Hasil Produk Tani Untuk Meminimalkan Pengeluaran Masyarakat Desa Wonorejo Kecamatan Glagah KAB. LAMONGAN. Empowering: Jurnal Pengabdian Masyarakat, 3, 88-98. 